\title{
The Comprehension of Indonesian Idiom in Indonesian speakers
}

\author{
S. S. Sofyaningrat \\ ${ }^{1}$ Department of Linguistics, Universitas Indonesia
}

\begin{abstract}
.
The study of how idioms are processed in human cognition is essential to find out whether the idioms are comprehended according to their idiomatic meanings that have one referent, or are comprehended according to the meaning of the words in the idioms. The majority of idiom comprehension studies that have been carried out are studies on English idioms, whereas for other languages the study of idiom has not been carried out, including in Indonesian. So the hypothesis related to comprehension of idioms cannot be said to be universal. This study aims to find out how the idioms are comprehended in Indonesian speakers' cognition. This is a preliminary study which employs qualitative method with two stage tests. The first stage is to find out the familiarity of Indonesian idioms for Indonesian speakers, and the second stage is to find out how those idioms are comprehended.
\end{abstract}

Keywords: idiom; psycholinguistics; language processing; language comprehension; Indonesian.

\section{Introduction}

Idioms are one type of non-literal language that is included in the metaphor. Metaphor according to Danesi (2004) shows the basic tendency of the human mind to think of certain referents at once. Idioms according to Cruse (1986) are expressions whose meaning does not refer to the literal meaning of their parts. Traxler (2012) states that in idioms, ordinary words that have literal meanings will have other meaning that is greater than the words in those idioms. Because of its unique form, the perception of idioms began to attract many studies to find out about how humans perceive idioms.

There are several theories to understand the process of perceptual idioms in human cognition. The classical theory of (Chomsky, 1980; Katz, 1973) states that idioms are processed in their entirety like the meaning of one word regardless of what the composers say. Listeners or readers do not access words individually. This model is also known as the Direct Access Model. (Gibbs, 1984; Schweigert, 1985, 1991).

Then, Hamblin \& Gibbs (1999) try to explain that idiom expressions have one meaning that is different from the literal meaning of the compiler, but the constituent words still contribute to the figurative meaning possessed by idioms, both decomposable idioms and non-compostable idioms. The theory supports the theory that literal meaning contributes to the overall meaning of idiomatic meaning called the Lexical Representation Model or Compositional Model (Glucksberg, 1993) 
However, Kreuz \& Graesser (1991) states that idiom research so far still has shortcomings, because the majority of studies always use English-language idioms, so idiomatic expressions are very limited. Because of this, conclusions from existing theories cannot reflect universal idiom theory. In the Indonesian language, the processing and understanding of idioms has not been widely studied. Research on many idioms focuses on research on translation and analysis of meaning by researchers. To find out how Indonesian language idioms are perceived by the native speaker, research is needed in relation to whether or not the idioms used as research are familiar or not. Because, research that does not consider these factors can be called inconsistent and contradictory results (Schweigert, 1985). Schweigert (1985) also added that whether or not an idiom would be familiar would affect the way humans perceive idioms. So, the authors conducted a study of idiom familiarity in Indonesian society first to find out which idioms were familiar and those who were less familiar. After that, this study aims to find out how Indonesian idioms are understood by Indonesian native speakers.

\section{Research Methodology}

This study employs qualitative methods. To achieve the objectives of this study, a twostage test was conducted, those are Idiom Familiarity Test and Idiom Comprehension Test.

\subsection{Idiom Familiarity Test}

The method used to test the level of Indonesian language idiom familiarity with Indonesian speakers is online surveys. The number of idioms that are assessed as being familiar is 30 idioms taken from the Dictionary of the Indonesian Language Expression (Chaer, 1997). 30 idioms are chosen because 30 of these idioms are assumed to be representations of familiar and unfamiliar idioms, also assumed to be not burdensome and do not require much time for the people who took part in the survey. This familiarity instrument was filled by 85 people with the following criteria:

- Indonesian speakers

- classified as young adults aged 20-40 years (Hurlock, 1980)

- does not have a formal education background in the field of language \& literature.

- not classified as people with special needs such as ADD, ADHD, aphasia, autism, and dyslexia.

The scale used is a 5 point scale. With a scale range of 1 for idioms that are unfamiliar to scale 5 which shows very familiar idioms. Then, the familiarity scale will be calculated on average for each idiom so that the idiom can be ranked according to the degree of creativity.

\subsection{Idiom Comprehension Test}

Tests for idiom understanding are done by distributing questionnaires to speakers of Indonesian with the same criteria as testing idiom familiarity. The number of participants is 20 people. Participants were told that a list of idioms in Indonesian would be displayed. The questionnaire contains two parts, interpreting the idiom meaning given directly and using the idiom in the context of a sentence. 


\section{Findings and Discussion}

The finding and discussion consists of two parts. First, the idiom familiarity test and the second is the Indonesian Idiom Comprehension.

\subsection{Idiom Familiarity Test}

The following are data on idiom familiarity in Indonesian:

\begin{tabular}{|c|c|c|c|c|}
\hline Rank & Idiom & Literal Meaning & Idiomatic Meaning & Average \\
\hline 1 & Adu domba & Sheep Fight & $\begin{array}{l}\text { Bring two parties or } \\
\text { more into conflict to } \\
\text { fulfil one's benefit }\end{array}$ & 4,81 \\
\hline 2 & Bahu-membahu & $\begin{array}{l}\text { Shoulder } \\
\text { shoulder }\end{array}$ & $\begin{array}{l}\text { To help each other, } \\
\text { together. }\end{array}$ & 4,74 \\
\hline 3 & Anak emas & Golden boy & $\begin{array}{lr}\text { Someone's } & \text { favourite } \\
\text { person. } & \text { (Boss' } \\
\text { favourite employee or } \\
\text { parents' favourite } \\
\text { child) }\end{array}$ & 4,72 \\
\hline 4 & Harga mati & Dead Price & $\begin{array}{l}\text { Prices that cannot be } \\
\text { changed. } \\
\text { Circumstances that } \\
\text { cannot be changed }\end{array}$ & 4,69 \\
\hline 5 & Salam Tempel & $\begin{array}{l}\text { Sticking } \\
\text { Handshake }\end{array}$ & Give bribe & 4,67 \\
\hline 6 & Cinta buta & Blind Love & $\begin{array}{l}\text { To love someone } \\
\text { while ignoring every } \\
\text { fault and imperfection } \\
\text { from that person in a } \\
\text { negative sense. }\end{array}$ & 4,59 \\
\hline 7 & Ambil pusing & Take a headache & $\begin{array}{l}\text { To care about } \\
\text { something }\end{array}$ & 4,55 \\
\hline 8 & Nyawa melayang & $\begin{array}{l}\text { Fleeting/Flying } \\
\text { Soul }\end{array}$ & To Die & 4,54 \\
\hline 9 & Air mata buaya & Crocodile's tears & $\begin{array}{l}\text { To act sad (When } \\
\text { actually is not) }\end{array}$ & 4,51 \\
\hline 10 & $\begin{array}{l}\text { Berada } \\
\text { dipersimpangan } \\
\text { jalan }\end{array}$ & At a crossroad & $\begin{array}{l}\text { Doubt in deciding a } \\
\text { choice }\end{array}$ & 4,35 \\
\hline 11 & Sampai hati & Arrive at the heart & No mercy & 4,15 \\
\hline 12 & $\begin{array}{l}\text { Berada di atas } \\
\text { angin }\end{array}$ & On top of the wind & Lucky & 4,07 \\
\hline 13 & Berakal panjang & Long mind & $\begin{array}{l}\text { To overcome all kinds } \\
\text { of difficulties }\end{array}$ & 4,06 \\
\hline 14 & Mengambil jarak & Take the distance & $\begin{array}{ll}\text { No } & \text { longer } \\
\text { close/friendly }\end{array}$ & 4,06 \\
\hline 15 & $\begin{array}{l}\text { Berada di atas } \\
\text { awang-awan }\end{array}$ & Above the air & Very Happy & 3,82 \\
\hline
\end{tabular}




\begin{tabular}{|c|c|c|c|c|}
\hline 16 & Jalur hijau & Green line & $\begin{array}{l}\text { City lane planted with } \\
\text { trees }\end{array}$ & 3,69 \\
\hline 17 & $\begin{array}{l}\begin{array}{l}\text { Berada di } \\
\text { garis }\end{array} \\
\end{array}$ & Outside the line & To not interfere & 3,65 \\
\hline 18 & $\begin{array}{l}\text { Bermandikan } \\
\text { Cahaya }\end{array}$ & Bath with lights & $\begin{array}{l}\text { Very bright light } \\
\text { conditions }\end{array}$ & 3,45 \\
\hline 19 & Beradu mata & Colliding eyes & $\begin{array}{l}\text { Gaze or look at each } \\
\text { other }\end{array}$ & 3,36 \\
\hline 20 & Percaya angin lalu & $\begin{array}{l}\text { Believe in the past } \\
\text { wind }\end{array}$ & $\begin{array}{l}\text { Believe in the news } \\
\text { that is not necessarily } \\
\text { true }\end{array}$ & 3,32 \\
\hline 21 & Adu lidah & Colliding tongue & To argue & 3,26 \\
\hline 22 & Macan ompong & Toothless tiger & $\begin{array}{l}\text { Rulers who no longer } \\
\text { have power }\end{array}$ & 2,91 \\
\hline 23 & Biaya Siluman & $\begin{array}{l}\text { Mystical creature's } \\
\text { money }\end{array}$ & Bribe. Illegal money & 2,86 \\
\hline 24 & Asap hitam & Black smoke & $\mathrm{Sad} / \mathrm{bad}$ situation & 2,72 \\
\hline 25 & Menjadi Angin & Being the wind & $\begin{array}{l}\text { Vanished without a } \\
\text { trace }\end{array}$ & 2,61 \\
\hline 26 & Berbalik akal & $\begin{array}{l}\text { The mind which } \\
\text { turn around }\end{array}$ & Crazy. Insane. & 2,58 \\
\hline 27 & $\begin{array}{l}\text { Menyebelahkan } \\
\text { hati }\end{array}$ & $\begin{array}{l}\text { To set the heart } \\
\text { aside }\end{array}$ & Share the love & 2,46 \\
\hline 28 & Membawa kaki & To carry feet & $\begin{array}{l}\text { Go without direction } \\
\text { and destination }\end{array}$ & 2,35 \\
\hline 29 & $\begin{array}{l}\text { Bulan jatuh di } \\
\text { haribaan }\end{array}$ & $\begin{array}{l}\text { Moon falls on the } \\
\text { lap }\end{array}$ & To Get a huge benefit & 2,29 \\
\hline 30 & Alas Perut & abdominal pads & $\begin{array}{l}\text { The first food to be } \\
\text { eaten in the morning }\end{array}$ & 2,21 \\
\hline
\end{tabular}

Table. 1. Indonesian idiom familiarity

Table 1 above illustrates the level of idiom familiarity from the most familiar with a value of 4.81 and the least familiar idiom has an average value of 2.21. From these data, they are grouped into two categories, which are familiar and unfamiliar idioms. A familiar idiom is assumed to be an idiom that has an average value above 3.50. Then, the results of 17 familiar idioms and 13 unfamiliar idioms were obtained.

\subsection{Idiom Comprehension Test}

The idiom comprehension test is divided into two parts to see differences in idiom familiarity with the process of understanding. From the results of idiom familiarity, only 24 idioms were taken which were divided into 12 of the most familiar idioms and 12 of the most unfamiliar idioms. Whereas 6 idioms that have middle values are ignored. Here are the results: 


\subsubsection{Familiar Idiom Comprehension Test}

Table 2 shows how the familiar idioms are accessed by Indonesian native speakers. For discussion, idioms are discussed with code I (idioms).

\begin{tabular}{|l|l|l|l|}
\hline Code & Idiom & Direct access (\%) & Lexical access (\%) \\
\hline I1 & Adu domba & 95 & 5 \\
\hline I2 & Bahu-membahu & 100 & 0 \\
\hline I3 & Anak emas & 75 & 25 \\
\hline I4 & Harga mati & 50 & 50 \\
\hline I5 & Salam Tempel & 100 & 0 \\
\hline I6 & Cinta buta & 0 & 100 \\
\hline I7 & Ambil pusing & 70 & 30 \\
\hline I8 & Nyawa melayang & 100 & 0 \\
\hline I9 & Air mata buaya & 100 & 0 \\
\hline I10 & $\begin{array}{l}\text { Berada di } \\
\text { persimpangan } \\
\text { jalan }\end{array}$ & 60 & 40 \\
\hline I11 & Sampai hati & 100 & 0 \\
\hline I12 & $\begin{array}{l}\text { Berada di atas } \\
\text { angin }\end{array}$ & 100 & 0 \\
\hline \multicolumn{2}{|l|}{ Average value } & 87.08 & 12.91 \\
\hline
\end{tabular}

Table. 2. Familiar idiom result test

From the following table, the difference can be seen in the fig 1.

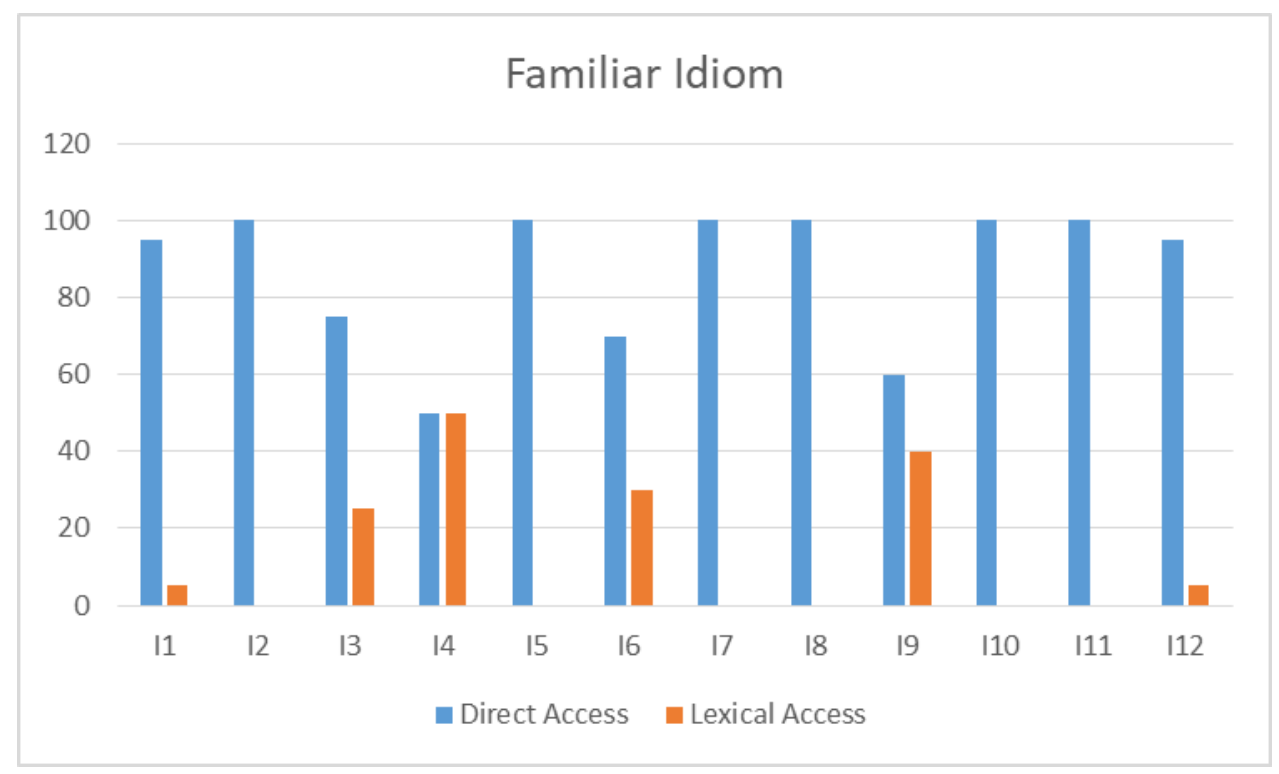

Fig. 1. Familiar idiom 
From Fig. 1 it can be seen that in understanding Indonesian idioms, native speakers use direct access models. After knowing that the words are idioms, the respondents immediately look for their idiomatic meanings and ignore the words that compose them. Only in a few idioms, there are some people who use the meaning of the constituent words. This is because I3, I4, I6, and I9 are idioms whose constituent meaning does affect the original meaning.

\subsubsection{Less Familiar Idiom Comprehension Test}

In table 3, the result of less familiar idioms comprehension test is shown.

\begin{tabular}{|l|l|l|l|}
\hline Code & Idiom & $\begin{array}{l}\text { Direct access } \\
(\boldsymbol{\%})\end{array}$ & $\begin{array}{l}\text { Lexical access } \\
(\mathbf{\%})\end{array}$ \\
\hline I13 & Beradu mata & 95 & 5 \\
\hline I14 & Percaya angin lalu & 10 & 90 \\
\hline I15 & Adu lidah & 25 & 75 \\
\hline I16 & Macan ompong & 95 & 5 \\
\hline I17 & Biaya Siluman & 65 & 35 \\
\hline I18 & Asap hitam & 65 & 35 \\
\hline I19 & Menjadi Angin & 55 & 45 \\
\hline I20 & Berbalik akal & 85 & 15 \\
\hline I21 & Menyebelahkan hati & 60 & 40 \\
\hline I22 & Membawa kaki & 80 & 20 \\
\hline I23 & Bulan jatuh di haribaan & 75 & 25 \\
\hline I24 & Alas Perut & 90 & 10 \\
\hline Average Value & 63.33 & 36.66 \\
\hline
\end{tabular}

Table. 3. Less Familiar Idiom Comprehension Test Result

To be able to see a clearer picture, the following is a diagram of the test results:

\section{Less Familiar Idiom}



Fig. 2. Less Familiar Idiom 
The diagram in Fig. 2 shows that in Less familiar idioms, most Indonesian speakers still use direct access, which is 63\% the average value. Direct access and lexical access are almost balanced in comprehension. Here, it can be seen that in less familiar idioms, respondents try to interpret idiomatic meanings with the help of their constituent words. Even so, direct access to idiomatic meanings still proved to occupy the highest comprehension. Therefore, this finding support the theory of Direct Access Model. (Gibbs, 1984; Schweigert, 1985, 1991)

\subsection{Conclusion}

From the survey results related to idiom familiarity in 30 idioms, 17 familiar idioms were found and 13 unfamiliar idioms. Furthermore, this data can be used for advanced idiom comprehension studies to find out how familiar and unfamiliar idioms are perceived by human cognition. In the idiom comprehension test, it can be seen that most Indonesian speakers directly access their idiomatic meanings especially in very familiar idioms. In unfamiliar idioms, most Indonesian speakers still use direct access, although it cannot be denied, that the constituent words still affect the comprehension.

As a preliminary study, this study is certainly has its setbacks. This study provides an initial overview and research framework for understanding how idioms are processed in human cognition. The number of idioms used in the test and also the increasing number of respondents involved in research will make this research better.

\section{Acknowledgements}

I would like to show my gratitude to all people that have supported and helped me in writing this paper, especially to Indonesia Endowment Fund for Education (LPDP) that have been supporting my study and sponsoring this research.

I would also like to thank my lectures in Universitas Indonesia for sharing knowledge with me during the course of this research.

\section{References}

1. Brenner, Gail. (2003). Websters' New World American Idioms Handbook. USA: Webster's new world

2. Chaer, Abdul. (1997). Kamus Ungkapan Bahasa Indonesia. Jakarta: PT Rineka Cipta.

3. Cruse, D.A. (1986). Lexical semantics. Cambridge: Cambridge University Press

4. Danesi, Marcel. (2004). Messages, Signs, and Meanings (3rd ed.). Toronto: Canadian Scholars' Press Inc.

5. Hamblin, J. L., \& Gibbs, R. W., Jr. (1999). Why you can't kick the bucket as you slowly die: Verbs in idiom comprehension. Journal of Psycholinguistic Research, 28(1), 25-39. http://dx.doi.org/10.1023/A:1023235403250.

6. Hurlock, Elizabeth B. (1980). Psikologi Perkembangan: Suatu Pendekatan Sepanjang Rentang Kehidupan. Jakarta: Gramedia.

7. Katz, J. (1973). Compositionality, idiomaticity, and lexical substitution. In S. Anderson \& P. Kiparsky (Eds.), A festschrift for Morris Halle. New York: Holt, Rinehart, \& Winston. 
8. Kreuz, R. J., \& Graesser, A. C. (1991). Aspects of idiom interpretation: Comment on Nayak and Gibbs. Journal of Experimental Psychology: General, 120(1), 90-92. http://dx.doi.org/10.1037/0096-3445.120.1.90.

9. Schweigert, W.A. (1986) The comprehension of familiar and less familiar idioms. Journal of Psycholinguistics Research. New York: Kluwer Academic PublishersPlenum Publishers. https://doi.org/10.1007/BF01067390.

10. Schweigert, W.A. (1991) The muddy waters of idiom comprehension. Journal of Psycholinguist Research. New York: Kluwer Academic Publishers-Plenum Publishers. https://doi.org/10.1007/BF01074283.

11. Traxler, Matthew J. 2012. Introduction to Psycholinguistics: Understanding Language Science. West Sussex: Wiley-Blackwell.4 Fine Tuning 